\title{
Potential of Social Science Outdoor Learning Laboratory in Singgahan District, Tuban
}

\author{
Sukma Perdana Prasetyaa, ${ }^{1, *}$ Sarmini ${ }^{2,}$ Ita Mardiani Zain ${ }^{3,}$ Artono $^{4,}$ FX. Sri Sadewo ${ }^{5,}$ \\ Hanifah Mahat ${ }^{6}$
}

$1,2,3,4,5$ Universitas Negeri Surabaya, Indonesia

${ }^{6}$ University Pendidikan Sultan Idris, Selangor, Malaysia

*Corresponding author.Email: sukmaperdana@unesa.ac.id

\begin{abstract}
The purpose of this study is to (1) identify the strengths and weaknesses of the locations that become "Karst Geoparks" as IPS outdoor learning laboratories (2) identify opportunities and obstacles from locations that become "Karst Geoparks" as IPS outdoor learning laboratories. This research is descriptive quantitative through direct field observations, Forum Group Discussion (FGD) activities, questionnaires, and documentation. The research was conducted in the "Geopark Karst" area of Singgaha-Tuban District as an area for the Social Sciences outdoor learning laboratory. The research subjects were 40 teachers who were members of the Social Sciences MGMP in Bojonegoro and Tuban Regencies. A total of 40 social sciences teachers have visited locations that become social sciences outdoor learning laboratories. The data analysis technique in this study is to examine all data from various sources, both from the results of questionnaires, field observations, personal documents, and official documents. The data is processed through data grouping, classification according to the order of problems, and classification of internal and external factors as well as analyzing supporting and inhibiting factors. After that do the strategy preparation using SWOT analysis. The potential for developing outdoor learning in Singgahan-Tuban District based on SWOT analysis is in quadrant I, the potential recommendations are given are progressive. The most supportive internal factors are outdoor learning locations close to each other in one sub-district and the many variations of population adaptation to the phenomenon of karst topography. The most hindering external threat at the moment is the ongoing COVID-19 pandemic which can stop all outdoor learning activities.
\end{abstract}

Keywords: laboratory, outdoor learning, Social Science.

\section{INTRODUCTION}

Outdoor learning is learning that can make students active by inviting students to identify plants directly so that learning becomes meaningful and mastery of concepts or cognitive learning outcomes can be empowered. The character of experience-based outdoor learning has shown various advantages. Interesting and experience-based natural environmental conditions are an important complement to the development of scientific activities[1]. Effective outdoor learning activities in the natural environment are characterized by active activities in exploration, being in the environment, real-life learning, sensory-motor involvement, and local [2].
Outdoor learning is an effort to direct students to carry out activities that can lead them to change their behavior towards the surrounding environment. So teaching outside the classroom involves students more directly with the environment around them, according to the material being taught. So that education outside the classroom refers more to experience and environmental education (natural and social) which greatly influences the intelligence of students. The Utilization of outdoor learning as a source of social sciences learning is very important. Learning resources should be carried out not only in the schoolyard but in the natural environment and the surrounding built environment must be utilized. Experiential education and the use of various interactive and outdoor learning environments should be an important part of social sciences learning [3]. 
Outdoor learning promotes and builds on the concept of sustainability, interest in nature, and environmental sensitivity both physically and socially. Social sciences teachers can plan, provide teaching materials or guidebooks and facilitate learning during outdoor learning activities. The method does not place too much emphasis on environmental problems and situations. Rather, it starts from the environment around students, their daily life, knowledge, skills, and interests.

Social sciences learning is not only oriented to the development of knowledge and skills but is also related to the way humans fulfill their needs in terms of material, culture, and soul [4]. Social Sciences is an integrated subject from various fields such as history, geography, anthropology, economics, and sociology. Outdoor learning is a vehicle for fostering the character of love and care for the environment so that students can solve environmental problems (nature and social), utilize existing resources on earth wisely and wisely, and have a sense of responsibility.

The application of outdoor learning in social sciences learning can be carried out in various places, one of which has potential is the "Karst Geopark" area in Singgahan District, Tuban Regency. Identification of potential outdoor learning locations must be consistently reviewed and designed as well as possible so that it can be applied to everyday life so that it becomes unique and unique.

Theoretically, the Singgahan district-Tuban has a unique diversity of learning resources because the Singgahan District is part of the Karst topography (lime lithology) of South Tuban which is rich in features such as caves, water sources, dolina, hot springs, waterfalls, ponor, etc. The people of Singgahan-Tuban Subdistrict also have various patterns of life in various livelihoods, tourism, culture, religion, and society to adapt to the natural conditions of the karst topography. Karst's potential in Singgahan District can be identified as a "Geopark" to be used as an outdoor learning social science laboratory.

The focus of outdoor learning varies across contexts. Outdoor learning in the Singgahan-Tuban Karst Geopark area, for example, has been described as kinesthetic learning, contextual and imaginative based, sensory, experience or discovery and carried out with peers; and therefore, according to practitioners, the learning is different from the classroom approach. According to Harris [5], especially the sensory-motor aspects of learning have been studied as different from learning in classroom activities because sensory-motor experiences cannot be fully obtained in the classroom.

Many studies show the advantages of outdoor learning, but Suyitno et al., [6] stated that teachers still have difficulty in developing learning outside the classroom using observation techniques. Therefore, various outdoor learning developments are needed to support learning outside the classroom. Outdoor learning activities must be well planned.

Planning for outdoor learning activities includes identifying potential outdoor learning locations, compiling guidebooks, preparing activity schedules, costs, and so on. This study aims to (1) identify the strengths and weaknesses of the locations that become "Karst Geoparks" as IPS outdoor learning laboratories (2) identify opportunities and obstacles from locations that become "Karst Geoparks" as IPS outdoor learning laboratories.

\section{METHODS}

This research is descriptive quantitative through direct field observations, Forum Group Discussion (FGD) activities, questionnaires, and documentation. The research was conducted in the Geopark Karst area, Singgahan-Tuban District as an area of the Social Sciences outdoor learning laboratory. The research subjects were 40 teachers who were members of the Social Science MGMP in Bojonegoro and Tuban Regencies. A total of 40 social science teachers have visited locations that become social science outdoor learning laboratories so that they can assess or provide reviews about the conditions of these locations. The primary data sought is about the actual conditions at the location such as object attraction, infrastructure, human resources, promotions, ticket prices, accessibility. The secondary data sought is about accessibility data and data on supporting facilities around the location. The locations for outdoor learning activities are 1) Nglirip waterfall, Batu Van Tuban, Mbah Jabar's tomb, Mbah Ganyong's tomb (one complex), 2) Krawak water source, 3) Ndodol dam, 4) Nganget baths, 5) Lowo Cave, 6) Karts tower Goa terus, 7) Putri cave.

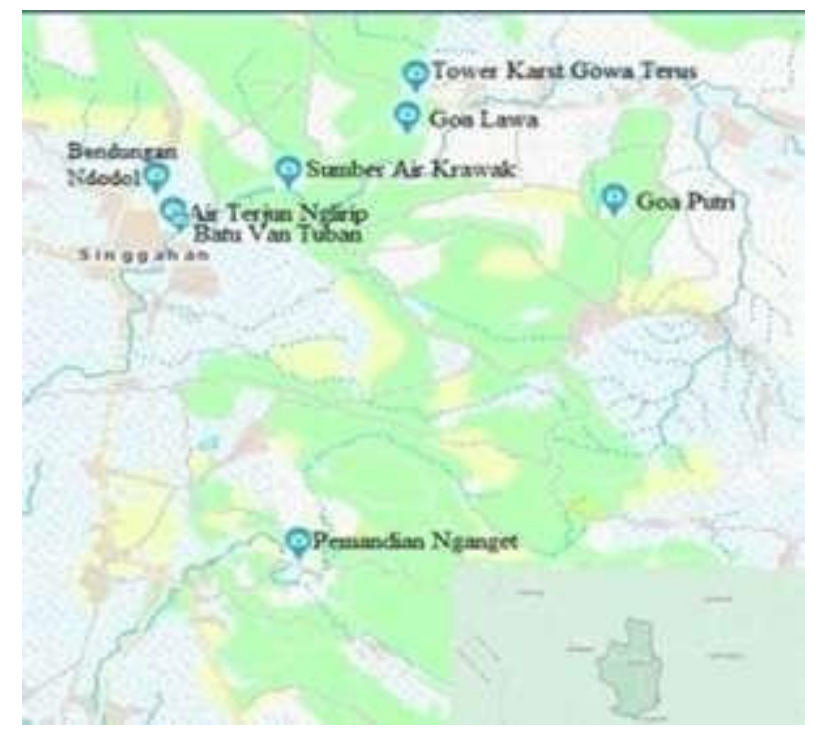

Figure 1 Location of the Social Sciences outdoor learning laboratory in Singgahan District, Tuban 
Data collection techniques used were observation, FGD, questionnaires, and documentation. Observations were made to describe the condition of outdoor learning locations such as human resources, accessibility, promotion, and those concerning tourism development strategies. The FGD was held to describe outdoor learning activities in Singgahan-Tuban District, as well as to get feedback from social science teachers about experiences and obstacles as well as the potential for outdoor learning activities if implemented. After carrying out the FGD, questionnaires were administered to social science teachers to obtain information about the potential of the Singgahan-Tuban karst area as an outdoor learning social science laboratory. Documentation is carried out to obtain primary data to support the research objectives.

The data analysis technique in this study is to examine all data from various sources, both from the results of questionnaires, field observations, personal documents, and official documents. The data is processed through data grouping, classification according to the order of problems, and classification of internal and external factors as well as analyzing supporting and inhibiting factors. After that do the strategy preparation using SWOT analysis.

\subsection{Scoring Criteria for Supporting/Inhibiting Internaland External Factors}

Determination of the internal variables (strengths and weaknesses) and external (opportunities and threats) that support or hinder them are then scored according to the following criteria:

Very Good: score 5

Good: score 4

Currently: score 3

Not Good: score 2

Very Bad: score 1

maximum score: $\Sigma$ number of respondents $\times$ the highest score

minimum score: $\Sigma$ number of respondents $\times$ the lowest score

maximum score: $\Sigma 40 \times 5=200$

minimum score: $\Sigma 40 \times 1=40$

middle value: $=120$

Determination of internal and external variables that enter into supporting variables is a score of 121 to 200 while inhibiting a score of 40 to 120 .

\subsection{Potential Analysis of Social Sciences Outdoor Learning Laboratory with SWOT}

- Arrange in column 1 a list of the main factors that have an important impact on the success or failure of the business consisting of various internal factors and external factors of the outdoor learning laboratory.

- Give the weight of each factor in column 2 with the paired comparison method or the paired comparison method. This method is used to provide an assessment of the weight of each internal and external determinant [7]. The weight of each variable is obtained by determining the value of each variable to the total value of the entire variable using the formula:

$$
a i=\frac{x i}{n}
$$

Information:

$$
\begin{aligned}
& \text { ai }=\text { the weight of the variable } I \\
& x i=\text { the value of the variable-I } \\
& I=1,2,3, \ldots, n \\
& n=\text { Number of variables }
\end{aligned}
$$

- Calculates the rating in column 3 for each factor by giving a scale ranging from 4 (very favorable) to 1 (very detrimental) based on the influence of these factors on the outdoor learning area.

$\begin{array}{ll}\text { Interval } & \text { Rating } \\ 161-200 & 4 \\ 121-160 & 3 \\ 81-120 & 2 \\ 40-80 & 1\end{array}$

- Multiplying the weight in column 2 by the rating in column 3 , to obtain a score for each weighting factor in column 4.

- Add up the weighting scores in column 4, to obtain the total weighting score for the potential for outdoor learning.

\section{RESULTS AND DISCUSSION}

\subsection{Results}

\subsubsection{Geographical Condition}

Efforts to improve the quality of social science learning through outdoor learning activities were carried out in Singgahan District, Tuban district, East Java. Singgahan District is an area that naturally has karst topography characteristics. Various adaptations that become residents' activities can be science interdisciplinary from the topographical conditions of the karst.

Singgahan District is $125 \mathrm{~km}$ from the city of Surabaya, the capital city of East Java. Singgahan subdistrict has an area of $14.62 \mathrm{~km} 2$ excluding state forest. Some of the areas that are the locations for outdoor learning are in the form of forests under the management of Perum Perhutani KPH Parengan. The forest in Singgahan District is a type of tropical rain forest that is a water catchment area and water source for the area. 


\subsubsection{Climate Condition}

The location of outdoor learning in Singgahan District has a source from Krawak which has an altitude of 124 meters above sea level. The average air temperature is $25 \mathrm{oC}-35 \mathrm{oC}$. Annual rainfall is estimated at $1,936 \mathrm{~mm}$ divided into 2 seasons, namely the rainy season (around November-May) and the dry season (June-October). The average monthly rainfall is around $440 \mathrm{~mm}$ during high rainfall during the rainy period and $0 \mathrm{~mm}$ during the dry month during the dry season (Singgahan District in 2015 figures).

\subsubsection{SWOT Analysis (Strength, Weakness,} Opportunities, and Threats) Potential of Karst Geopark in Singgahan-Tuban Sub-district as an outdoor learning laboratory for Social Sciences

SWOT analysis is one of the techniques that can identify the potential of "Karst Geopark" in SinggahanTuban District as a social science outdoor learning laboratory. SWOT components include strength, weakness, opportunity, and threats. The four SWOT components need attention so that they can help the identification process of outdoor learning laboratories.

\subsubsection{Internal Factor Evaluation (IFE)}

Identifying internal factors needs to be done to find out the strengths and weaknesses of the potential "Karst Geopark" Singgahan-Tuban District as an outdoor learning social science laboratory. Information about the internal conditions of the location was obtained through a questionnaire with social science teachers in Tuban and Bojonegoro districts who had visited outdoor learning locations.

Internal factors that support it are the attractiveness of the object of the outdoor learning laboratory location which includes (1) the proximity of the location, (2) the completeness of the karst phenomenon, (3) location management, and (4) variations in the adaptation of the population in the location. Internal factors that become obstacles are (1) the high cost of outdoor learning activities, (2) the large allocation of time for activities, (3) the availability of transportation and accommodation facilities, and (4) the absence of a guidebook. The results of the IFE matrix can be seen in table 1 .

Table 1. IFE Matrix of IPS Outdoor Learning Laboratory

\begin{tabular}{|c|c|c|c|c|}
\hline No & Internal potential factors & Weight & Rating & Score \\
\hline \multicolumn{5}{|c|}{ STRENGTH } \\
\hline 1 & Outdoor learning locations are close to each other in one district & 0,176471 & 4 & 0,529412 \\
\hline 2 & Have an attraction with the complete karst phenomenon & 0,117647 & 4 & 0,235294 \\
\hline 3 & Management of well-established outdoor locations & 0,117647 & 3 & 0,235294 \\
\hline 4 & $\begin{array}{l}\text { Variations in population adaptation to karst phenomena in outdoor learning } \\
\text { locations }\end{array}$ & 0,147059 & 3 & 0,367647 \\
\hline & Subtotal & 0,558824 & & 1,367647 \\
\hline \multicolumn{5}{|c|}{ WEAKNESS } \\
\hline 1 & It costs a lot & 0,176471 & 2 & 0,529412 \\
\hline 2 & It takes a lot of time & 0,117647 & 1 & 0,235294 \\
\hline 3 & Availability of transportation and accommodation facilities & 0,088235 & 2 & 0,132353 \\
\hline \multirow[t]{3}{*}{4} & There is no guidebook yet. & 0,058824 & 1 & 0,058824 \\
\hline & Subtotal & 0,441176 & & 0,955882 \\
\hline & Total & 1 & & 2,323529 \\
\hline
\end{tabular}

\subsubsection{External Factor Evaluation (EFE)}

Identifying external factors needs to be done to find out the opportunities and threats in the Karst Geopark potential of Singgahan-Tuban District as an outdoor learning social science laboratory. Information about the internal conditions of the location was obtained through a questionnaire with social science teachers in Tuban and Bojonegoro regencies who had visited outdoor learning locations. The supporting external factors are (1) the K-13 curriculum which leads to innovative learning such as $\mathrm{PjB1}$, inquiry learning, (2) improving abilities: cognitive, affective, social/interpersonal and physical/behavioral, (3) holding local cultural activities in the location of outdoor learning, (4) can become a tourism objectbased on nature, education, culture, and special interests (religion, rock climbing, rapids, outbound). Threats from external factors are (1) environmental damage due to logging in upstream areas/water sources, 
(2) awareness of residents and visitors in maintaining environmental cleanliness, such as waste management, (3) the unfinished covid 19 pandemic, and (4) Floods and landslides during the rainy season, and drought in the dry season. The results of the EFE matrix can be seen in table 2 .

Table 2. EFE Matrix of IPS Outdoor Learning Laboratory

\begin{tabular}{|c|c|c|c|c|}
\hline No & External potential factors & Weight & Rating & Score \\
\hline \multicolumn{5}{|c|}{ OPPORTUNITIES } \\
\hline 1 & $\begin{array}{l}\text { The K-13 curriculum that focuses on innovative learning such as } \mathrm{PjBl} \text {, } \\
\text { inquiry learning, and so on }\end{array}$ & 0,137931 & 4 & 0,275862 \\
\hline 2 & $\begin{array}{l}\text { Ability enhancement: cognitive, affective, social/interpersonal and } \\
\text { physical/behavioral }\end{array}$ & 0,137931 & 3 & 0,275862 \\
\hline 3 & Local cultural activities held at outdoor learning locations. & 0,103448 & 3 & 0,155172 \\
\hline 4 & $\begin{array}{l}\text { Can be a nature-based, educational, cultural and interest-based tourist attraction } 1 \\
\text { (religion, rock climbing, rafting, outbound) }\end{array}$ & 0,172414 & 4 & 0,431034 \\
\hline & Subtotal & 0,551724 & & 1,137931 \\
\hline \multicolumn{5}{|c|}{ THREATS } \\
\hline 1 & Environmental damage due to deforestation in upstream areas/water sources & 0,103448 & 2 & 0,155172 \\
\hline 2 & $\begin{array}{l}\text { Awareness of residents and visitors in maintaining environmental cleanliness, } \\
\text { such as waste management }\end{array}$ & 0,068966 & 1 & 0,068966 \\
\hline 3 & Pandemic Covid 19 & 0,206897 & 2 & 0,62069 \\
\hline 4 & $\begin{array}{l}\text { Disasters of floods and landslides during the rainy season, as well as drought } \\
\text { in the dry season }\end{array}$ & 0,068966 & 1 & 0,068966 \\
\hline & Subtotal & 0,448276 & & 0,913793 \\
\hline & Total & 1 & & 2,051724 \\
\hline
\end{tabular}

The results of the IFE table above the value of the strength factor (strength) is 1.367647 and the value of the weakness factor is 0.955882 , the difference in the value of the strength and weakness factor is used to determine the $\mathrm{x}$-axis (0.411764706). Based on the results of the EFE table above, the opportunity factor value is 1.137931, and the threat factor value is 0.913793 , the difference between the opportunity and threat factor values is used to determine the y-axis (0.224138).

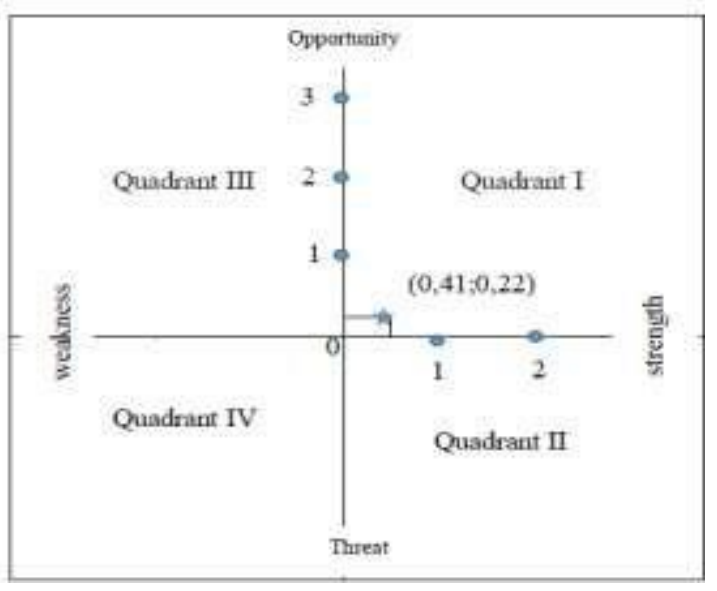

Figure 2 SWOT Analysis Result

\subsection{Discussion}

Based on the SWOT analysis, it is shown that the location of the quadrant in the image is in quadrant I, precisely at the point ( $\mathrm{x} 0.41$ and y 0.22 ). This position shows strong potential and opportunity, the strategy recommendation given is Progressive, meaning that the potential is in prime and steady condition so that it is very possible to continue to expand, increase growth and achieve maximum progress. This quadrant is located between external opportunities and internal strengths (growth strategy), namely the potential designed to achieve social science outdoor learning activities. The potential of area "karst Geopark" Singgahan-Tuban District for the location of the IPS outdoor learning laboratory is included in the potential for rapid growth, which is a strong factor to maximize the utilization of all opportunities.

Based on the highest score, internal factors in the form of outdoor learning locations close to each other in one sub-district and the many variations in population adaptation to the karst phenomenon in outdoor learning locations are the main factors that make this area an outdoor learning social science laboratory. The location of outdoor learning that is close together and the variation of population 
adaptation in dealing with environmental conditions is a "local potential|" unique in each region.

The local potential is a resource that exists in a certain area. The local potential has meaning as a source/strength possessed by each region to be utilized in certain activities [8]. Local potential develops from the wisdom tradition possessed by an unpretentious society as part of its culture. Juniati and Sari [9] explained that learning based on local potential can be a means of contextual learning, utilization, and preservation of local potential, as well as forming good student character, especially for the environment. Local potential-based learning can also increase students' living values including the character of honesty, cooperation, and responsibility [10]. Mulyani et al.,[11] also mention that regional potential can be developed in the form of teaching materials. Implementation of local potential-based learning can be delivered with learning strategies outside the classroom so that students gain hands-on experience.

Based on the acquisition of the highest score of external factors, namely the opportunity to become a tourism object based on nature, education, culture, and special interests (religion, rock climbing, rapids, outbound). This means that social science learning activities strongly support an interdisciplinary approach that activates cognitive, affective, skills to physical activities. In their extensive meta-analysis of studies on outdoor learning, Rickinson et al., [12] found four types of impact of outdoor learning activities: cognitive (knowledge, understanding, and other academic outcomes), affective (attitudes, values, beliefs, and self-perceptions), social/interpersonal (communication skills, teamwork, and leadership) and physical /behavior (physical fitness, physical skills, personal behavior, and social actions)

The potential of outdoor learning for social science learning activities is very beneficial. Learning outside the classroom is learning that focuses on student learning activities carried out outside the classroom ([13]; [14]. Outdoor learning is an educational approach that focuses on the environment with actioncentered characteristics and thematic learning processes [15]. The advantages of outdoor learning include providing opportunities for students to gain real, practical, and concrete experiences, can foster a sense of pleasure, interest, and motivation towards certain objects, and bring students closer to the environment. The results of research by Kurniangsih et al[16]., reveal that learning using outdoor learning as a learning resource is very effective in measuring conceptual understanding of environmental utilization and preservation.

Based on the highest score, the threat factor is the COVID-19 pandemic. The threat of this COVID-19 pandemic can stop all outdoor learning activities because the public (including students) are required not to do much activity outside the home and strictly adhere to health protocols by doing $3 \mathrm{M}$, namely wearing masks, washing hands, and maintaining distance. The COVID-19 pandemic is the biggest risk in the current implementation of outdoor learning activities. according to Mannion, et all., [17]; Rickinson et al.,[12]), while there are many advantages to outdoor learning, there are also many obstacles to overcome. These barriers include fears and concerns about health and safety, lack of confidence of teachers to teach outside the classroom, and the ratio of costs incurred.

\section{CONCLUSION}

The results of the analysis and discussion that have been described previously, the conclusions regarding the potential development of "Karst Geopark" Singgahan-Tuban District as an outdoor learning social science laboratory are as follows:

- Internal factors that become the most potential strengths are outdoor learning locations close to each other in one sub-district and the many variations of population adaptation to the karst phenomenon in outdoor learning locations. Meanwhile, the internal factor that is the most weakness of potential development is that outdoor learning activities are expensive when compared to other learning methods.

- External factors that are the most potential opportunities, namely the outdoor learning location area can become a tourism object based on nature, education, culture, and special interests (religion, rock climbing, rapids, outbound). Meanwhile, the external factor that poses the most threat is the ongoing COVID- 19 pandemic.

- The potential of "Karst Geopark" in SinggahanTuban District as an appropriate social science outdoor learning laboratory based on SWOT analysis measured by quantitative methods through the calculation of the coordinate position is in quadrant I. This position indicates a strong and potential condition, the strategic recommendations are given are progressive, meaning that the organization is in prime and stable condition so that it is very possible to continue to expand, enlarge growth and achieve maximum progress. 


\section{REFERENCES}

[1] K. Sandell and J. Öhman, "Educational potentials of encounters with nature: Reflections from a Swedish outdoor perspective," Environ. Educ. Res., 2010, doi: 10.1080/13504620903504065.

[2] R. Ballantyne and J. Packer, "Introducing a fifth pedagogy: experience-based strategies for facilitating learning in natural environments," Environ. Educ. Res., 2009, doi: 10.1080/13504620802711282.

[3] S. P. Prasetya, "Lingkungan Geografis Sebagai Sumber dan Media Pembelajaran Ilmu Pengetahuan Sosial," in Penguatan Pendidikan IPS Menghadapi Isu-isu Global, 2018, [Online]. Available: http://eprints.ulm.ac.id/4162/2/1. Penguatan Pendidikan IPS pdf.

[4] S. I. Suharwati and A. M. Rahman, "Menumbuhkan Karakter Cinta Lingkungan dalam Pembelajaran IPS di Sekolah Dasar Melalui Outdoor Study,” Pros. Semin., 2018.

[5] F. Harris, "The nature of learning at forest school: practitioners' perspectives," Educ. 3-13, 2017, doi: 10.1080/03004279.2015.1078833.

[6] S. Imam, Kamal Mustofa, Sunoto, and S. Indra, "Environmental Observation Learning Techniques Based on Local Wisdom," J. Chem. Inf. Model., 2016.

[7] Rangkuti, “Analisis Swot-Teknik Membedah Kasus Bisnis. Cara Perhitungan Bobot, Rating, dan OCAI," Penerbit PT. Gramedia Pustaka Utama, 2017.

[8] I. Hatimah, "Management of Local PotentialBased Learning in PKBM," J. Mimb. Pendidik., 2006.

[9] E. Juniati and W. Sari, "Integration of Local Potential in SL Learning on the Formation of Learner Softskills to Solve Environmental Problems," in Symposium on Biology education, 2016.

[10] S. Sarah and Maryono, "The Effectiveness of Local Potential-Based Learning in High School Physics Learning in Improving Students' Living Values," J. Sci. Educ., vol. 2, no. 1, pp. 36-42, 2014.

[11] S.Mulyani, S.W. Harti, \& Z. Hendri, "Development of Regional Potential-Based Teaching Material Models to Support Javanese Language Learning," J. Kependidikan Penelit. Inov. Pembelajaran, 2013, doi: 10.21831/jk.v43i1.2250.

[12] C. Rickinson, M., Dillon, J., Teamey, K., Morris, M. and P. M. Y., Sanders, D. and Benefield, A review of research on outdoor learning. Preston Montford, Shropshire: Field Sciences Council, 2004.

[13] I. G. H. K. Anitah, S., Juleha, S., Wardani, Learning Strategy in Elementary School. Jakarta: Open University, 2008.

[14] S. P. Prasetya, N. B. Segara, and A. Imron, "Effectiveness Of Outdoor Learning Optimization Program In Learning Social Sciences," JPI (Jurnal Pendidik. Indones., vol. 9, no. 2, p. 314, 2020, doi: 10.23887/jpiundiksha.v9i2.19160.

[15] P. E. Gustafsson, A. Szczepanski, N. Nelson, and P. A. Gustafsson, "Effects of an outdoor education intervention on the mental health of schoolchildren," J. Adventure Educ. Outdoor Learn., 2012, doi: 10.1080/14729679.2010.532994.

[16] A. Kurniangsih, D. Darsiharjo, and E. Maryani, "Penggunaan Metode Pembelajaran Outdoor Study Terhadap Pemahaman Konsep Pelestarian Lingkungan Hidup Peserta Didik di MTsN Singaparna," J. Geogr. Gea, 2016, doi: 10.17509/gea.v15i1.4180.

[17] M. Mannion, G., Mattu, L., \& Wilson, "Teaching, learning, and play in the outdoors: a survey of school and preschool provision in Scotland," Scottish Natural Heritage Commissioned, 2015. http://www.snh.org.uk/pdfs/publications/commis sioned_reports/779.pdf. 